\section{Aantekening redactie}

Voor noodweer is vereist dat de verdediging is gericht tegen een 'ogenblikkelijke, wederrechtelijke aanranding'. Van een 'ogenblikkelijke' aanranding is ook sprake bij een onmiddellijk dreigend gevaar voor een aanranding. Enkele vrees voor zo'n aanranding is daartoe echter niet voldoende. De gestelde aanranding moet in redelijkheid beschouwd zodanig bedreigend zijn voor de verdachte dat deze kan worden aangemerkt als een ogenblikkelijke aanranding in de zin van artikel $41 \mathrm{Sr}$. In deze zaak heeft de verdachte met een ijzeren staaf de voorruit van de auto van de vader van aangever ingeslagen op het moment dat aangever in de auto van zijn vader weg wilde rijden. De verdachte stelde echter dat de angever met gierende banden op hem af kwam en het slaan met de staaf dus zelfverdediging was. Het hof achtte wel aannemelijk dat angever met hoge snelheid in de richting van verdachte is gereden, maar verwierp het beroep op noodweer(exces) met een onduidelijke redenering:

'Het hof is, gelet op het voorgaande, van oordeel dat vanwege de gedragingen van verdachte en het feit dat verdachte op het moment van slaan al heeft waargenomen dat [benadeelde] met snelheid langs hem heen rijdt, hetgeen op dat moment niet als meer dan een bedreiging kan worden aangemerkt en er bovendien geen sprake was van een omstandigheid die de verwachting kon rechtvaardigen dat [benadeelde] verder zou gaan dan een dreiging, maakt dat tot het moment dat verdachte overgaat tot het daadwerkelijk slaan met de staaf op de auto, er sprake was van een zodanige wederkerigheid in de mate van agressie, dat dit in de weg staat aan het slagen van een beroep op noodweer door verdachte. Immers, onder de gegeven omstandigheden is geen sprake van een onmiddellijke mederrechtelijke aanranding. Het hof ziet de hierboven beschreven beoordeling van de situatie bevestigd in de opmerkingen van verdachte tijdens zijn verhoor bij de politie over zijn handelen: "Eigenlijk wilde ik hem laten schrikken" en "Het was helemaal niet mijn bedoeling. Het was [benadeelde] zijn auto helemaal niet, maar die van zijn vader". Naar het oordeel van het hof zijn dat geen opmerkingen die passen bij iemand die meende doodgereden te worden.'

Hierin vallen elementen te ontwaren van culpa in causa, het ontbreken van verdedigingswil alsmede het ontbreken van een ogenblikkelijke aanval. De basis voor de verwerping lijkt echter het ontbreken van een ogenblikkelijke wederrechtelijke aanranding te zijn. Het verrast niet dat de motivering volgens de Hoge Raad niet zonder meer begrijpelijk was:

'In het licht van de door het Hof vastgestelde feiten en omstandigheden, in het bijzonder de vaststellingen van het Hof betreffende de wijze waarop [benadeelde] twee keer met hoge snelheid met een auto is afge- reden op de verdachte, is die motivering niet zonder meer begrijpelijk.'

\section{NTS 2020/16}

\author{
HR 8 oktober 2019, 18/02750, ECLI:NL:HR: \\ 2019:1548
}

\begin{abstract}
Hennepteelt, art. 3.B Opiummet. Onttrekking aan het verkeer van inbeslaggenomen boksbeugel, art. $36 d \mathrm{Sr}$. Is voldaan aan voormaarde dat boksbeugel kan dienen om soortgelijk feiten te begaan?
\end{abstract}

\section{Aantekening redactie}

Het hof heeft de verdachte in deze zaak wegens 'opzettelijk handelen in strijd met een in artikel 3 onder B van de Opiumwet gegeven verbod', veroordeeld tot een gevangenisstraf voor de duur van vier maanden, waarvan twee maanden voorwaardelijk en met een proeftijd van twee jaren. Voorts heeft het hof de onttrekking aan het verkeer bevolen van een in beslag genomen en nog niet teruggeven boksbeugel. Artikel $36 \mathrm{~d} \mathrm{Sr}$ luidt als volgt:
'Vatbaar voor onttrekking aan het verkeer zijn boven- dien de aan de dader of verdachte toebehorende voor- werpen van zodanige aard dat het ongecontroleerde bezit daarvan in strijd is met de wet of met het algemeen belang, welke bij gelegenheid van het onderzoek naar het door hem begane feit, dan wel het feit waarvan hij wordt verdacht, zijn aangetroffen, doch alleen indien de voormerpen kunnen dienen tot het begaan of de voorbereiding van soortgelijke feiten, dan wel tot de belemmering van de opsporing daarvan.'

Met een boksbeugel kan moeilijk hennep worden geteeld. Onder soortgelijke feiten in de zin van deze bepaling dienen te worden verstaan feiten die tot dezelfde categorie behoren als de door de verdachte begane feiten dan wel de feiten waarvan hij wordt verdacht. ${ }^{12}$ In aanmerking genomen dat is bewezen verklaard dat de verdachte ongeveer 426 hennepplanten heeft geteeld, valt zonder nadere motivering, die ontbreekt, niet in te zien hoe de onder de verdachte in beslag genomen boksbeugel kan dienen tot het telen van hennep of soortgelijke misdrijven, dan wel tot de belemmering van de opsporing daarvan. Het middel klaagt daarover terecht, volgens de Hoge Raad.

12. HR 6 mei 1997, ECLI:NL:HR:1997:ZC9322. 
$\mathrm{Nu}$ het voorhanden hebben van een boksbeugel een strafbaar feit oplevert, zou overigens onttrekking van de boksbeugel aan het verkeer bij afzonderlijke beschikking op de voet van artikel $36 \mathrm{~b}$ lid 1 onder $4^{\circ}$ jo. artikel $36 \mathrm{c}$ onder $2^{\circ} \mathrm{Sr}$ tot de mogelijkheden kunnen behoren.

\section{NTS 2020/17}

\section{HR 1 oktober 2019, 19/00827, ECLI:NL:HR:} 2019:1472

\author{
Cassatie in belang der met. Beschikking Rb inhoudende \\ toemijzing verzoek ex art. $36 \mathrm{~Sv}$ tot verklaring dat zaak \\ geëindigd
}

\section{Aantekening redactie}

Volgens artikel $36 \mathrm{~Sv}$ 'kan het gerecht in feitelijken aanleg, voor hetwelk de zaak het laatst werd vervolgd, op het verzoek van den verdachte of op voordracht van de rechter-commissaris op de voet van artikel 180, verklaren dat de zaak geëindigd is indien een vervolging niet wordt voortgezet'.

In deze cassatie in het belang der wet werd een drietal vragen betreffende de uitleg van artikel $36 \mathrm{~Sv}$ voorgelegd aan de Hoge Raad:

'1. Op welk moment neemt "vervolging" a.b.i. art. $36 \mathrm{~Sv}$ aanvang?

2. Kan verklaring ex art. $36 \mathrm{~Sv}$ dat zaak is geëindigd worden gegeven wanneer onderzoek ttz. aanvang heeft genomen?

3. Kan overschrijding van redelijke termijn ex art. 6.1 EVRM grond bieden voor geven van verklaring dat zaak is geëindigd?'

Het betrof hier een beschikking van Rechtbank NoordNederland, zittingsplaats Groningen, van 23 mei 2018 waarbij een verzoek ex artikel $36 \mathrm{~Sv}$ tot verklaring dat de zaak geëindigd is, is toegewezen. In die beschikking heeft de rechtbank het verzoek van de verdachte om te verklaren dat de zaak is geëindigd ex artikel $36 \mathrm{~Sv}$, toegewezen op een moment waarop het onderzoek ter terechtzitting al was aangevangen. De vraag was of dat rechtens kon. Naast deze vraag speelden in de rechtspraktijk nog twee andere vragen met betrekking tot de uitleg van artikel $36 \mathrm{~Sv}$. De eerste was wat onder 'vervolging' in de zin van artikel $36 \mathrm{~Sv}$ moet worden verstaan en meer in het bijzonder of het artikel toepassing kan vinden in gevallen waarin nog geen rechter op vordering van de officier van justitie in de zaak is betrokken. De tweede was aan de hand van welke maatstaf moet worden beoordeeld of de zaak 'niet wordt voortgezet' in de zin van het artikel. Meer in het bijzonder was de vraag of de overschrijding van de redelijke termijn grond kan opleveren om te verklaren dat de zaak geëindigd is. Ook deze twee vragen werden in de vordering aan de Hoge Raad ter beantwoording voorgelegd. Zij raken namelijk, net als de vraag die in de bestreden beschikking primair aan de orde was, de functie die aan artikel $36 \mathrm{~Sv}$ in de hedendaagse strafrechtspleging toekomt. De antwoorden van de Hoge Raad op deze vragen - die er overigens toe leidden dat het oordeel van de rechtbank getuigt van een onjuiste rechtsopvatting ${ }^{13}$ - worden hieronder integraal weergegeven:

4.3

Het in art. $36 \mathrm{~Sv}$ bedoelde verzoek kan worden gedaan ingeval van "vervolging" van een zaak. Naar hedendaagse rechtsopvatting vangt de vervolging als bedoeld in art. 36, eerste lid, Sv aan op het moment dat vanwege de Nederlandse Staat jegens de betrokkene een handeling is verricht waaraan deze in redelijkheid de verwachting kan ontlenen dat tegen hem ter zake van een bepaald strafbaar feit door het openbaar ministerie een strafvervolging zal worden ingesteld. Vanaf dat moment - en niet eerst vanaf het moment dat het openbaar ministerie de strafrechter betrekt in de strafzaak - kan de verdachte immers belang hebben bij het inroepen van het oordeel van de rechter omtrent het geëindigd zijn van de zaak.

4.4

In de systematiek van het Wetboek van Strafvordering ligt besloten - zoals onder meer tot uitdrukking komt in het voorschrift van art. 266, eerste lid, Sv dat ertoe strekt dat de officier van justitie de dagvaarding niet meer kan intrekken zodra het onderzoek ter terechtzitting is aangevangen - dat, nadat het onderzoek ter terechtzitting is aanvangen, de procedure wordt voortgezet totdat een einduitspraak is gegeven door de zittingsrechter. Daarmee verhoudt zich niet dat een verklaring dat de zaak is geëindigd, wordt verzocht en gegeven op het moment dat het onderzoek ter terechtzitting een aanvang heeft genomen en door de zittingsrechter nog niet onherroepelijk einduitspraak is gedaan. In die situatie dient de verdachte in het verzoek als bedoeld in art. $36 \mathrm{~Sv}$ niet-ontvankelijk te worden verklaard.

Onder omstandigheden kan een verdachte wel worden ontvangen in een verzoek als bedoeld in art. 36 $\mathrm{Sv}$ nadat de einduitspraak onherroepelijk is geworden. Dat kan onder meer het geval zijn indien bij de einduitspraak de onbevoegdheid van de rechter of de nietigheid van de dagvaarding is uitgesproken.

4.5

13. De rechtbank had de verdachte dus niet-ontvankelijk behoren te verklaren in het verzoek als bedoeld in art. $36 \mathrm{~Sv}$. 